\title{
Effects of Macroeconomic Volatility on Stock Prices in Kenya: A Cointegration Evidence from the Nairobi Securities Exchange (NSE)
}

\author{
Muinde Patrick Mumo ${ }^{1}$ \\ ${ }^{1}$ School of Finance, Central University of Finance and Economics, Beijing, China \\ Correspondence: Muinde Patrick Mumo, School of Finance, Central University of Finance and Economics \\ (CUFE), 39 South College Road, Beijing, 100081, China. Tel: 86-132-6008-5756 (China)/ 254-723-584-928 \\ (Kenya).E-mail: pmmumo@yahoo.com
}

Received: November 10, 2016

Accepted: December 5, 2016

Online Published: January 10, 2017

doi:10.5539/ijef.v9n2p1

URL: http://dx.doi.org/10.5539/ijef.v9n2p1

\begin{abstract}
This study examined the effects of macroeconomic volatility on stock prices via selected macro variables using the Johansen co-integration methodology. Time series data was obtained from the Kenya National Bureau of Statistics (KNBS) and the Central Bank of Kenya (CBK) for the period 1998-2015. Macro variables studied include inflation, money supply, exchange rates and interest rates against the NSE 20 share index. The study exploits the presence of unit roots of order 1(1) on the data set to apply the Johansen procedure and the Vector Error Correction Model (VECM) for data analysis.

The study finds both a long-run equilibrium relationship between stock prices and the macroeconomic variables and between inflation and other macro variables. Specifically, and contrary to earlier evidence on the Kenyan market, the results suggest a negative long-run equilibrium relationship between money supply and stock prices. Inflation shows negative but insignificant relationship. Exchange rates and interest rates show a positive relationship. The short-term dynamics from the VECM support earlier documented evidence, implying the earlier evidence reflect short-run and not long-run dynamics.

The study concludes that the effects of inflation seem to outweigh any possible gains from money supply on aggregate firm output in the long-run. Also, the study adduces evidence of possible spurious problems on earlier documented evidence from the reviewed studies that could be attributable to non stochastic processes in the models used. A robustness check using a multivariate approach points to this and confirms the co-integration results.
\end{abstract}

Keywords: stock prices, macroeconomic variables, Nairobi securities exchange, co-integration and evidence

\section{Introduction}

Over the past decade, the stability of the inflation rate has been a key focus of the macroeconomic policy in Kenya, with a target to maintain it at the one digit level (less than 10 percent). Since the 1980s, Kenya has experienced a turbulent macroeconomic environment attributable to political uncertainty and changing weather patterns that significantly affect agricultural output, traditionally the mainstay economic activity. Macroeconomic instabilities affect economic growth and development and empirical evidence from economic literature suggest volatility in certain variables get priced in stock markets.

The effect of macroeconomic variables on stock prices is still a subject of intense study. The commonly studied variables include inflation, exchange rates, industrial productivity, interest rates, money supply and short-term interest rates. However, empirical studies on these variables continue to give divergent results from one market to another and even over different time periods in the same market.

In Kenya, studies by Ouma and Muriu (2014), Ochieng and Oriwo (2012) and Aroni (2011) have focused on inflation, interest rates, money supply and exchange rates with conflicting evidence as to the direction of the effect. Further, these studies have focused on different time periods, mainly less than five years and after 2007. Only Ouma and Muriu (2014) considered a longer-term of 10 years (2003 to 2013). This study looks at an 18 year, monthly data series to examine both the long-run and short-run effects of the macro variables on the stock prices. Thus, this is the longest time series ever done for the Kenyan market and the first to explore both the long-run and short-run dynamics. 
A simple plot of key macroeconomic variables demonstrates the volatility of the macro environment in Kenya: Figure 1.

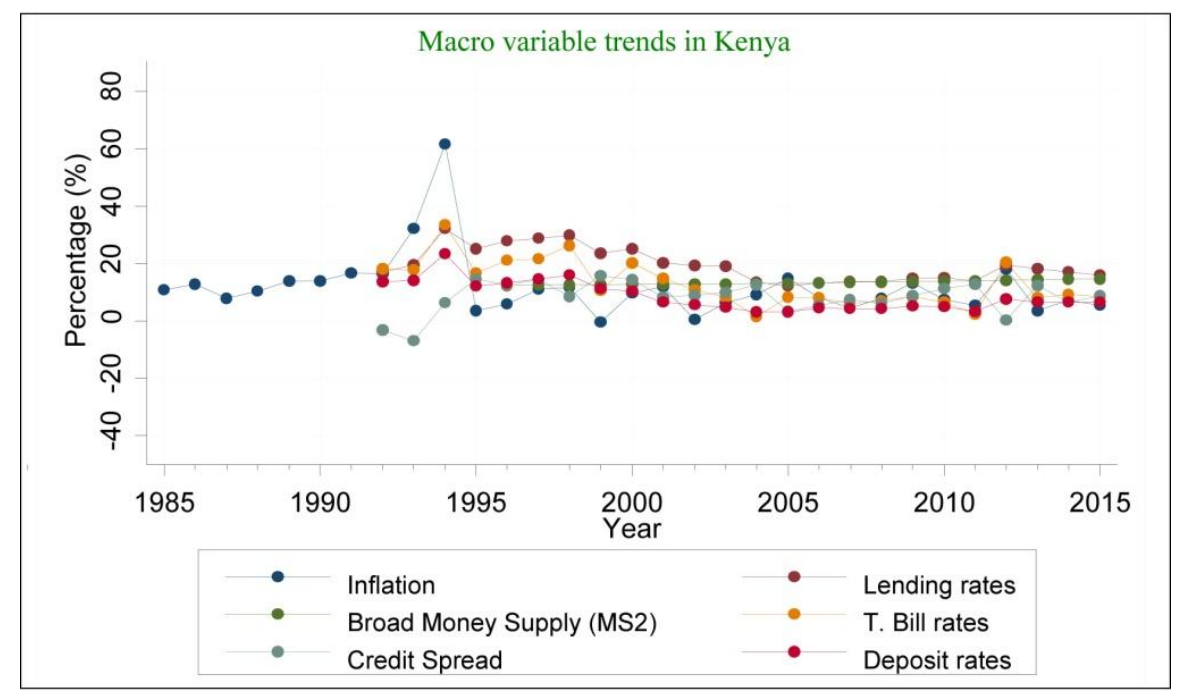

Figure 1. A plot of macroeconomic trends

Inflation has particularly been volatile, rising to over 60 percent in 1993. The 91-day Treasury bill rates (T. Bills) were quite volatile in the early 1990's, peaking at 85 percent in July 1993. Since the mid 1990's, the rates have remained relatively erratic and high at over 10 percent, and rose to over 20 percent in 2012 . The movements in the T. bill rates is an indicator of the CBK interventions to address underlying macroeconomic shocks, either through the discount rate window or the Open Market Operation (OMO). The credit spread (the difference between commercial banks weighted lending rates and interbank rates) have consistently remained high at over 10 percent.

However, of interest here is whether there are any relationships between the volatility in these macroeconomic variables and the stock prices. The study investigates the effect of selected macroeconomic variables on the NSE 20 share index (value weighted) monthly prices. The macroeconomic variables examined are log monthly Consumer Price Index (InCPI) -measure for inflation, log average monthly exchange rates (Kenya Shilling (KES) to the US dollar (US\$)), log credit spread, log average monthly money supply (broad money supply (M2) includes M1 (Note 1), quasi money in banks, and quasi money in Non Bank Financial Institutions (NBFI's)).

This study contributes to the increasing literature on the relations between macroeconomic variables and stock prices from emerging markets. The study adduces evidence on the long-run equilibrium relationship between stock prices and selected macroeconomic variables in Kenya. In addition, the study makes the first attempt to explore short-run dynamics and long-run relations between stock prices and macro variables in Kenya.

Further, the study provides empirical evidence that delineates between variables with lagged and contemporaneous relations with stock prices. This proffers insights for monetary policy interventions in the economy. Also, this the longest time series so far applied on the Kenyan market, and provides a window to establish better long-run equilibrium relationships. Ultimately however, the study contributes empirical evidence into the scantly available academic literature from the emerging markets of Africa.

The rest of the study is organized as follows: part 2 reviews relevant literature, part 3 discusses data sources and description of the variables. Part 4 discusses the identification strategy while part 5 presents and discusses the main results. Conclusion is done on part 6.

\section{Relevant Literature}

\subsection{Brief Background}

Since the emergence of evidence on the failure of the Capital Asset Pricing Model (CAPM) to predict stock returns with data after the $1960 \mathrm{~s}$, the factors that determine stock returns have been a subject of intense study over the last four decades (Reinganum, 1981; Lakonishok \& Shapiro, 1986; Fama \& French, 1993). Other famous studies on the subject include Chen, Roll, \& Rose, 1986; Erb, Harvey, \& Viskanta, 1995 \& 1996; Harvey, 
1995; De Jong \& De Roon, 2001; Borys, 2007; Ericsson \& Karlsson, 2004).

Generally, several factors including spreads between long and short-term interest rates, expected and unexpected inflation, industrial productivity, credit risk spread between high and low grade bonds, term structure, country credit rating, market segmentation, and momentum have been found to be priced in stock markets with data from both developed and emerging markets.

\subsection{Empirical Evidence}

Naik and Padhi (2012) find that macroeconomic variables and the stock market index (BSE Sensex) are co-integrated and thus a long-run equilibrium relationship exists between them in the India stock market. They find a positive relationship between stocks prices and money supply, and industrial production, but a negative relationship for inflation. From their study, exchange rates and short-term interest rates are insignificant in determining stock prices. Separate studies by Kumar (2013) and Patel (2012) find a long-run relationship exists between stock returns and various macroeconomic variables in the Indian stock market.

Benakovic and Posedel (2010) examine the sensitivity of asset returns for fourteen firms to various macroeconomic variables on the Croatian stock market. They find the market index, interest rates, oil influence; as well as industrial production have a positive relation with returns, while inflation has a negative influence. However, only the market index and oil influence have a statistically significant effect.

Talla (2013) investigates the effects of selected macroeconomic variables on stock prices of the Stockholm Stock Exchange. He finds inflation and currency depreciation have a significant negative influence on stock prices. Further, he finds an insignificant negative relationship for interest rates and a positive one for money supply.

On a study of the US market, Flanner and Protopapadakis (2002) find inflation and money supply as the significantly correlated macroeconomic factors while CPI, Production Price Index (PPI), Balance of Trade, Employment report and housing starts are not significant. From these findings, only money supply affects both the level and volatility of equity returns; CPI only affects the level returns.

Tangjitprom (2012) examines the effects of various macroeconomic variables on stock performance in Thailand. He finds they can explain stock returns after adjusting for lags. From the study, interest rate is the most important macroeconomic variable to explain variance in stock returns. However, he finds that even though stock performance can predict future variability of most of the macroeconomic factors, the factors cannot predict future performance of stock returns. Also, the study finds that all macroeconomic variables can only explain a small variance in stock returns.

Aurangzeb (2012) looks at the effects of various macroeconomic factors on the stock market returns of South Asian countries of Pakistan, India and Sri Lanka. The results indicate Foreign Direct Investment (FDI), and exchange rates have significant positive impact on stock performance while interest rates have a significant negative impact. Inflation is found to have negative, but insignificant impact.

Studies on the effects of macroeconomic variables on the Kenyan stock market seem to suggest mixed results. Olweny and Omondi (2011) investigate the volatility of stock returns at the NSE to various macroeconomic variables and finds exchange rates, inflation and interest rate affect stock return volatility. Aroni (2011) analyzes macroeconomic factors influencing stock prices for firms listed at the NSE between 2008 and 2010. He finds a negative relationship between stock returns and exchange rates and interest rates, but a positive relationship between inflation and money supply with stock returns. Ochieng and Oriwo (2012) examine the relationship between stock performance and macroeconomic variables using the NSE all share index (NASI), and finds a negative relation between the 91-day T. bill rate, and a weak positive relationship for inflation and the index.

However, in addition to the too short data time series, Aroni (2011) and Ochieng and Oriwo (2012) studies fails to check whether the time series are stationary or the order of stationarity if any. This poses the risk of biased results since non-stationary time series could lead to spurious results in regression models (Wooldridge, 2013).

Further, for a time series to give the best linear unbiased results, it must be consistent with the Gauss -Markove theorem (assumptions) including linear parameters, no perfect collinearity, zero conditional means, homoskedasticity and no serial correlations. Aroni (2011) and Ochieng and Oriwo (2012) analyses appears to have given a wide berth and/or remained silent on these time series technicalities. The current study addresses this through tests for unit roots and utilizes the Johansen (1991) and/or Johansen and Juselius (1990) co-integration approach, and VECM framework (Enders, 2004; Brooks, 2008).

Ouma and Muriu (2014) examine the impact of the various macroeconomic variables on stock returns at the NSE. They find money supply, exchange rate and inflation rate to have a significant impact on stock returns in Kenya, 
with money supply and inflation showing a positive impact and exchange rate a negative impact. Interest rate is found to be an unimportant factor.

It is clear from the foregoing literature that macroeconomic variables continue to give different outcomes from the various markets and therefore remain a subject for continued research. This study explores the subject further with a specific focus on the Kenyan market.

\subsection{A Synopsis of the Research Question}

An identification problem, too short data series and possible data management technicalities could probably explain the contradictory outcomes on studies done for the Kenyan market. For instance, with evidence from Fama and French (1993) 3 factor model, Carhart (1997) 4 factor model and Ericsson and Karlsson (2004) Bayesian approach on factors that ought to be considered in multifactor models, the validity of CAPM must be confirmed first in any study that suggests its use. This approach has not been taken on the studies reviewed for the Kenyan market.

Further, the studies done in Kenya seems to suggest a very high explanatory power of the macro-variables on stock returns. Ouma and Muriu (2014) find macro variables explain up to 63\% (adjusted $\mathrm{R}^{2}$ of 0.636), Ochieng and Oriwo (2012) report a 64\% explanatory power (adjusted $\mathrm{R}^{2}$ of 0.582 ) while Aroni (2011) reports $87 \%$ explanatory power $\left(\mathrm{R}^{2}\right.$ of 0.870$)$. From empirical evidence on the determinants of stock returns from developed markets (Fama \& French, 1993; Cohart, 1997; and Ericsson \& Karlsson, 2004), these seemingly high $\mathrm{R}^{2}$ s warrant further investigation. Also, neither of the studies on the Kenyan market attempts to establish or explain if and whether the effects are contemporaneous or lagged.

\section{Data Sources and Description of Variables}

Monthly data are obtained from the websites of the KNBS and the CBK. Monthly value weighted NSE 20 share values, monthly CPI changes, and monthly inflation data are obtained from the monthly key economic indicator's reports from January 1998 to December 2015, available on the KNBS website (www.knbs.or.ke/). Average monthly money supply, monthly 90 day T. Bill rates, Exchange rates, Interbank rates and weighted average commercial bank interest rates were downloaded from the CBK website (www.centralbank.go.ke/).

For the purpose of data analysis, the log values for monthly value weighted NSE 20 share index, average monthly money supply, average monthly exchange rates, average national monthly CPI and credit spread are used. Short-term interest rates (proxy for risk free rate) is the average monthly 91-day $\mathrm{T}$. bills rates adjusted for a default premium of $3.25 \%$ consistent with a $\mathrm{B}+$ ranking of Kenyan sovereign bond in the international markets by credit rating agencies S\&P and Moody's. The variables are defined and described on Table 1.

Table 1. Description of variables

\begin{tabular}{llc}
\hline Acronyms & Construction of Variables & $\begin{array}{c}\text { Data } \\
\text { Source }\end{array}$ \\
\hline InNSER & $\begin{array}{l}\text { Natural logarithm of the weighted average market value of the NSE 20 share index month-end closing prices } \\
\text { (proxy for monthly market prices) }\end{array}$ & KNBS \\
InCPI & Natural logarithm for monthly average consumer price index ( measure of monthly inflation) & KNBS \\
InMS & Natural logarithm of the monthly average of broad money supply (M2) & CBK \\
InEXR & Natural logarithm of the average monthly exchange rate for the Kenya shilling(KES) against the US\$ (US dollar) & CBK \\
InCS & $\begin{array}{l}\text { Natural logarithm of the Credit Spread -difference between Commercial banks weighted average monthly lending } \\
\text { rates and the monthly average of interbank (overnight) borrowing rates(proxy for long term and short term interest }\end{array}$ & \\
& rates respectively) & CBK \\
\hline
\end{tabular}

Note. KNBS -Kenya National Bureau of Statistics monthly economic indicators reports; CBK-Central Bank of Kenya. All data are available online from the two institutions websites.

\section{Identification Strategy}

\subsection{Stationary and Non-Stationary Stochastic Process}

A time series refers to a collection of random variables ordered in time (a stochastic process) such as stock returns, GDP (t), inflation (t), interest rates among others. Such stochastic process is said to be (weakly) stationary if its time invariant (along with its autocovariance), that is, its mean and variance are constant over time. In contrast, a non-stationary time series has a time-varying mean or a time-varying variance or both.

This study exploits the concept of stationarity in time series to establish if their exists any equilibria relationships 
between stock prices and selected macroeconomic variables in Kenya by employing the Johansen (1991) and/or Johansen and Juselius (1990) co-integration tests and VECM model. The Johansen co-integration test is premised on the theory that the time series is non-stationary at level (or at order 1(0)) but stationary at first difference (or at order 1(1)), but the linear combination of the integrated variables is 1(0), and thus are said to be integrated (Enders, 2004). If the variables are co-integrated, then an equilibrium exist between the variables in the long-run.

\subsection{Unit Root Test}

The unit root concept and the subsequent test of their presence or not thereof in a time series are an important step in the Johansen's co-integration technique. A unit root test is one of the most popular approach used by researchers to determine if a stochastic process is stationary or not and if stationary, at what order. The presence of a unit root indicates that the data series is non-stationary. This study utilizes three common and widely used procedures of testing for unit root namely the Augmented Dickey Fuller (ADF), Phillips -Perron (PP) and Kwiatkowski-Phillips -Shin (KPSS) to test for unit roots in the time series.

Both the ADF and the PP test the Null hypothesis $\left(H_{0}\right)$ that the data set being tested has a unit root. However, both procedures have again been criticized as having low power if the process is stationary but with a root close to the non-stationary boundary. The KPSS tests the alternative hypothesis to ADF and PP, that is, the data set is level stationary $1(0)$, around which the two earlier tests are criticized as being weak. The unit root tests provide the order of integration of the time series variables, which is useful in deciding if the Johansen technique could be applied to the data set.

\subsection{The Johansen Co-integration Technique and VECM Framework}

This study is multivariate, and the unit root results (presented later) confirm the time series to be stationary at order 1(1). The Johansen method of co-integration can be expressed from the following vector autoregressive framework of order $\mathrm{p}$ as follows:

$$
y_{t}=V+A_{1} y_{t-1}+A_{2} y_{t-2}+\ldots \ldots \ldots+A_{p} y_{t-p}+\varepsilon_{t}
$$

Where:

$y_{t}=\mathrm{a} n \times 1$ vector of variables (non-stationary $1(1)$ variables)

$\mathrm{V}=\mathrm{a} \mathrm{n} \times 1$ vector of parameters

$A_{1}-A_{p}=$ are $\mathrm{n} \times \mathrm{n}$ matrices of parameters, and

$\varepsilon_{t}=\mathrm{a} \mathrm{nx} 1$ vector of disturbances (white noise terms). $\varepsilon_{t}$ has a mean of 0 , has a covariance matrix $\sum$, and is independently and identically distributed (i.i.d) normal over time.

This could then simply be summarized into the following equation:

$$
y_{t}=V_{0}+\sum_{j=1}^{p} A_{j} y_{t-j}+\varepsilon_{t}
$$

In order to use the Johansen's method, then equation (2) needs to be turned into a VECM that can be written as:

$$
\Delta y_{t}=V_{0}+\sum_{j=1}^{p-1} \Gamma_{j} \Delta y_{t-j}+\Pi y_{t-1}+\varepsilon_{t}
$$

Where:

$\Delta=$ first difference operator

$\Gamma_{j}=-\sum_{i=j+1}^{p} A_{j}$

$\Pi=-\mathrm{I}+\sum_{i=j+1}^{p} A_{j}$, and

$\mathrm{I}=\mathrm{a} \mathrm{n} \times \mathrm{n}$ identity matrix.

Engel and Granger (1987), shows that if the variables $y_{t}$ are a 1(1) the matrix $\Pi$ in (3) has a rank $0 \leq r<n$, where $r$ is the number of linearly independent co-integrating vectors. If the variables co-integrate, $0<r<n$ and (3) show that a VAR in first differences is misspecified because it omits the lagged level term $\Pi y_{t-1}$.

The test for co-integration between the y's is calculated by observing the rank of the $\Pi$ matrix via its eigenvalues. The rank of a matrix is equal to the number of its characteristics roots that are different from zero. The hypothesis is $H_{0}: \Pi=\alpha \beta^{\prime}$ where $\alpha$ and $\beta$ are $\mathrm{n} \times \mathrm{r}$ loading matrices of eigen vectors. The matrix $\beta$ gives the co-integration vectors, while $\alpha$ is a matrix of the adjustment parameters that give the amount of each co-integration entering each equation of the VECM. This aims to test the number of $\mathrm{r}$ co-integrating vectors such as $\beta_{1}, \beta_{2}, \ldots \ldots, \beta_{r}$ (Naik \& Padhi, 2012).

In cases where deterministic trends exist in the co-integrating VECM, the Johansen's framework allows for 
restriction flexibility for constant and linear trend. To allow for a constant and a linear trend on the assumption of $r$ co-integrating relations, the VECM (3) can be written as:

$$
\Delta y_{t}=\alpha \beta^{\prime} y_{t-1}+\sum_{j=1}^{p-1} \Gamma_{j} \Delta y_{t-j}+\mathrm{v}+\delta t+\varepsilon_{t}
$$

Where:

$\delta=\mathrm{an} \times 1$ vector of parameter.

Since equation (4) models the differences of the data, the constant implies a linear time trend in the levels, and the time trend $\delta t$ implies a quadratic time trend in the levels of the data. As often we may want to include a constant or a linear time trend for the differences without allowing for the higher order trend implied for the levels of the data, VECM exploits the properties of the matrix $\boldsymbol{\alpha}$ to achieve this flexibility. Given that $\boldsymbol{\alpha}$ is a n x r rank matrix, the deterministic components in (4) can be rewritten as:

$$
\begin{gathered}
\mathrm{V}=\alpha \mu+\gamma \\
\delta t=\alpha \rho t+\tau t
\end{gathered}
$$

Where $\mu$ and $\rho$ are $\mathrm{r} \times 1$ vectors of parameters and $\gamma$ and $\tau$ are $\mathrm{n} \times 1$ vectors of parameters. $\gamma$ is orthogonal to $\alpha \mu$ while $\tau$ is orthogonal to $\alpha \rho$ i.e. $\gamma^{\prime} \alpha \mu=0$ and $\tau^{\prime} \alpha \rho=0$. This allows us to rewrite (4) as:

$$
\Delta y_{t}=\alpha\left(\beta^{\prime} y_{t-1}+\mu+\rho t\right)+\sum_{j=1}^{p-1} \Gamma_{j} \Delta y_{t-j}+\gamma+\tau t+\varepsilon_{t}
$$

Adding these restrictions on the trend terms in (5) yields five cases including unrestricted trend, restricted trend, unrestricted constant, restricted constant and no trend. This study adopts a restricted trend, $\tau=0$. This specification allows the co-integrating equations to be trend stationary.

The number of characteristic roots can be tested through the trace statistics, and the maximum eigenvalue test as shown in the following equations:

$$
\lambda_{\text {trace }}(r)=-T \sum_{i=j+1}^{p} \operatorname{In}\left(1-\widehat{\lambda}_{J}\right) \text { and } \lambda_{\operatorname{Max}}(r, r+1)=-T \operatorname{In}\left(1-\hat{\lambda}_{r+1}\right)
$$

Where:

$\mathrm{r}=$ the number of co-integrating vectors under the null hypothesis;

$\mathrm{T}=$ the number of usable observations, and

$\hat{\lambda}_{j}=$ the estimated value for the $\mathrm{j}^{\text {th }}$ ordered characteristic roots or eigenvalue from the $\Pi$ matrix.

A significant eigenvalue indicates a significant co-integrating vector. The trace statistics is a joint test with the null hypothesis that the number of co-integrating vectors is less than or equal to $r$ against an unspecified general alternative that there are more than $\mathrm{r}$. The maximum eigenvalue statistic tests the null hypothesis that the number of co-integrating vectors is less than or equal to $r$ against the alternative of $r+1$. The presence of co-integrating vectors supports the application of a dynamic VECM that depicts the feedback process, and the speed of adjustment for short-run deviation towards the long-run equilibrium, and reveals short-run dynamics in any variables relative to others (Naik \& Padhi, 2012).

\section{Main Results and Discussion}

\subsection{Descriptive Statistics}

This study set out to examine if their exist equlibria relationships between stock prices on the Kenyan market as measured by the NSE 20 share index (InNSER), and the volatility of selected macroeconomic variable. The summary statistics are presented in Table 2:

Table 2. Descriptive statistics

\begin{tabular}{ccccccc}
\hline & InNSER & InCPI & InMS & InEXR & InCS & ATB \\
\hline Mean & 8.075 & 4.401 & 13.523 & 4.351 & 2.057 & 12.579 \\
Median & 8.156 & 4.356 & 13.393 & 4.357 & 2.194 & 11.69 \\
Maximum & 8.661 & 5.098 & 14.79 & 4.657 & 2.852 & 30.23 \\
Minimum & 6.934 & 3.745 & 12.644 & 4.083 & -3.504 & 4.08 \\
Std. deviation & 0.428 & 0.422 & 0.682 & 0.117 & 0.711 & 5.247 \\
Variance & 0.183 & 0.178 & 0.466 & 0.014 & 0.506 & 27.526 \\
Skewness & -0.863 & 0.072 & 0.355 & -0.122 & -3.861 & 1.302 \\
Kurtosis & 2.974 & 1.69 & 1.724 & 3.295 & 24.809 & 2.974 \\
Obs. & 216 & 216 & 216 & 216 & 216 & 216 \\
\hline
\end{tabular}

Source: Summarized from data set. 
The average monthly stock returns is 8.08 with a standard deviation of 0.43 , a median of 8.16 and a maximum of 8.661 with a minimum of 6.93 . The average inflation is 4.40 with a standard deviation of 0.42 , a median of 4.36 and a maximum of 5.10 with a minimum of 3.75 . The money supply average is 13.53 with a standard deviation of 0.68 , a median of 13.39 and a maximum of 14.79 with a minimum of 12.64 . The exchange rate average 4.35 with a standard deviation of 0.12 , a median of 4.36 and a maximum of 4.66 with a corresponding minimum of 4.08. The percentage change in credit spreads average 2.06 with a standard deviation of 0.71 , a median of 2.19 and a maximum of 2.85 with a minimum of -3.50 . Finally, the average monthly risk free rate is 12.58 with a standard deviation of 5.25, a median of 11.69 and a maximum of 30.23 with a minimum of 4.08 .

\subsection{Unit Root Tests and VAR Lag Order Selection}

A test for the presence of unit roots in the data set is a critical step in the Johansen's methodology. The technique utilizes the non-stationary properties of a time series, that is, stationary of order 1(1) and the VECM framework to establish if an equilibrium relationship exists among the variables.

Three procedures, the ADF, PP and KPSS test were done to test for stationarity. In ADF and PP test, the Null hypothesis $\left(H_{0}\right)$ is that the series has a unit root while in the KPSS the null is that the series is stationary at level i.e. 1(0). If the estimated t-statistics (absolute values) are larger than the asymptotic critical values at the $1 \%, 5 \%$ or $10 \%$ confidence levels, then we reject the null, and accept the alternative hypothesis. The unit root test results are presented in Table 3:

Table 3. Unit root tests for stationary

\begin{tabular}{|c|c|c|c|c|}
\hline \multirow[t]{2}{*}{ Variables } & ADF Test & PP Test & KPSS Test & \multirow[t]{2}{*}{ Order of Integration } \\
\hline & $H_{o}:$ Variable is non-stationary & Ho: Variable is non-stationary & Ho: Variable is stationary & \\
\hline InNSER & -2.94 & -2.331 & $1.39^{* * *}$ & \\
\hline$\Delta$ InNSER & $-3.227 * *$ & $-14.593^{* * *}$ & 0.187 & 1(1) \\
\hline InCPI & -3.167 & -3.218 & $1.49^{* * *}$ & \\
\hline$\Delta \mathrm{InCPI}$ & $-4.385^{* * *}$ & $-8.696^{* * *}$ & 0.095 & $1(1)$ \\
\hline InMS & -3.102 & -2.972 & $4.76^{* * *}$ & \\
\hline$\Delta \mathrm{InMS}$ & -3.084 & $-16.645 * * *$ & 0.191 & $1(1)$ \\
\hline InEXR & -2.114 & -1.951 & $1.93^{* * *}$ & \\
\hline$\Delta \operatorname{InEXR}$ & $-4.037 * * *$ & $-10.679 * * *$ & 0.125 & $1(1)$ \\
\hline InCS & $-4.171 * * *$ & $-9.842 * * *$ & $0.169^{* *}$ & $1(0)$ \\
\hline ATB & -2.218 & -3.155 & $2.42 * * *$ & \\
\hline$\triangle \mathrm{ATB}$ & $-5.481 * * *$ & $-10.479 * * *$ & 0.054 & $1(1)$ \\
\hline \multicolumn{5}{|c|}{ Asymptotic critical values } \\
\hline $1 \%$ & -4.006 & -4.002 & 0.216 & \\
\hline $5 \%$ & -3.436 & -3.435 & 0.146 & \\
\hline $10 \%$ & -3.136 & -3.135 & 0.119 & \\
\hline
\end{tabular}

Note. $* *$ implies significant at $1 \%$ level; ** implies significant at $5 \%$ level; * implies significant at $10 \%$ level. $\Delta$ represents first difference.

Based on the ADF test, we cannot reject the null for all variables except for inflation (CPI) that we could reject at 0.1 levels, and credit spread that we can reject at the 0.01 level in favour of the alternative. However, we can reject the null for inflation (CPI) based on the MacKinnon approximate p-values for $Z_{t}(0.0912)$ which is larger than acceptable 0.05 or less. On first difference test, we can reject the null in favour of the alternative for all variables except for money supply (rejected on second difference). Thus, we conclude that all variables have unit roots except credit spread.

From PP test, we cannot reject the null for all variables except for the credit spread at which the null is rejected at 0.01 levels. On first difference, we reject the null at 0.01 levels for all the variables. Therefore, we conclude that the time series have unit roots for all variables except for credit spread.

Finally, the KPSS test rejects the null for all variables in favour of the alternative. However, this test contradicts the ADF and PP tests on credit spread by not failing to reject the null at 0.05 confidence levels implying a unit root exist. For the purposes of further analysis, credit spread (InCS) is dropped forthwith since the Johansen technique exploits the property of stationary of order 1(1).

To select the lag levels, often the Sequential Modified LR test statistic (LR), Hanna-Quinn Information Criterion (HQIC) and Schwarz Information Criteria (SIC) are used to identify the lag order in the co-integration tests. The results for the VAR lag selection criteria are presented in Table 4. 
Table 4. VAR lag order selection criteria

\begin{tabular}{ccccccc}
\hline \multicolumn{7}{l}{ Endogenous variables: InNSER, InCPI, InMS, InEXR and ATB } \\
\hline Lag & LogL & LR & FPE & AIC & HQIC & SBIC \\
\hline 0 & -273.529 & & $9.50 \mathrm{E}-06$ & 2.6276 & 2.6596 & 2.7068 \\
1 & 1792.05 & 4131.2 & $4.20 \mathrm{E}-14$ & -16.6231 & -16.6231 & $-16.1481^{*}$ \\
2 & 1843.92 & 103.74 & $3.20 \mathrm{E}-14$ & -16.8766 & $-16.8766^{*}$ & -16.0058 \\
3 & 1868.21 & 48.588 & $3.20 \mathrm{E}-14$ & -16.8699 & -16.358 & -15.6033 \\
4 & 1892.11 & $47.790^{*}$ & $3.30 \mathrm{E}-14$ & -16.8595 & -16.1876 & -15.197 \\
\hline
\end{tabular}

Note. * denotes lag level selected by criteria.

The LR criterion selects a lag level of four and the HQIC selects a lag level of 2 with SIC picking a lag level of 1. All the information criterions fail to select a common lag level. With the hindsight that the lag levels help address problems of serial correlation in the error terms, the study adopts a lag level of 5 .

\subsection{Multivariate (Johansen) Co-Integration Test and VECM Results}

The Johansen (1991) and/or Johansen and Juselius (1990) procedure for testing co-integration is used to establish the presence and the number of co-integrating relationships and/or lack of them thereof. The trace statistic and the maximum eigenvalue test statistics are used to determine the number of co-integrating vectors. The results of the trace statistics and maximum eigenvalues are shown in Table 5:

Table 5. Trace statistic and maximum eigenvalues test results

\begin{tabular}{ccccc}
\hline Hypothesized No. of CE(s) & Trace Statistic & $\mathbf{0 . 0 5}$ Critical values & Max -eigen Statistic & 0.05 Critical values \\
\hline None* & 102.4380 & 68.52 & 53.9020 & 33.46 \\
At most 1 & 48.5360 & 47.21 & $22.5809^{* *}$ & 27.07 \\
At most 2 & $25.9552^{* *}$ & 27.68 & 18.7050 & 20.97 \\
At most 3 & 7.2501 & 15.41 & 7.0974 & 14.07 \\
At most 4 & 0.1527 & 3.76 & 0.1527 & 3.76 \\
\hline
\end{tabular}

Note. * denote rejection of the hypothesis at 0.05 level; ** denotes cannot reject the hypothesis at 0.05 level.

From the Johansen technique, the number of co-integrating vectors $r$ is the number set as null at which we fail to reject the null hypothesis under the trace statistics, and $r+1$ at which we fail to reject the null under the maximum eignvalue test. The null is rejected if the trace and maximum eigenvalue statistics are more than the critical values at either a specified 0.05 or 0.01 levels. In this study the critical values are set at 0.05 levels. From Table 5, both the trace statistic and maximum eigenvalue criterion identify that there are 2 co-integrating vectors in the data set at the set 0.05 levels (but 1 co-integrating vector at 0.01 levels).

Assuming two co-integrating vectors, the study applies the Johansen methodology to estimate the short-run and long-run interactions among the underlying variables. The results from the VECM procedure are presented in Table 6:

Table 6. Results of vector error correction model

\begin{tabular}{|c|c|c|c|c|c|c|c|}
\hline \multicolumn{8}{|c|}{ Panel A: Johansen Normalized Co-integration Coefficients } \\
\hline & & InMS & InCPI & InEXR & ATM & Trend & Constant \\
\hline \multirow[t]{3}{*}{ InNSER } & 1.0000 & -1.6829 & & $13.9538 * * *$ & $0.2392 * * *$ & -0.0207 & -51.8819 \\
\hline & & $(3.1116)$ & & $(2.9659)$ & $(0.0842)$ & $(0.0353)$ & \\
\hline & & {$[-0.54]$} & & [4.70] & [2.84] & {$[-0.59]$} & -26.1174 \\
\hline \multirow[t]{3}{*}{ InCPI } & 1.0000 & $1.7223 * * *$ & & 0.3865 & $-0.0591 * * *$ & $-0.0278 * * *$ & \\
\hline & & $(0.4125)$ & & $(0.3932)$ & $(0.1116)$ & $(0.0047)$ & \\
\hline & & [4.17] & & [0.98] & {$[-5.29]$} & {$[-5.94]$} & \\
\hline \multirow[t]{3}{*}{ InMS } & 1.0000 & & 0.5806 & 0.2244 & $-0.0343 * * *$ & $-0.0162 * * *$ & -15.1647 \\
\hline & & & $(0.6547)$ & $(0.2287)$ & $(0.0055)$ & $(0.0045)$ & \\
\hline & & & {$[0.89]$} & {$[0.98]$} & {$[-6.28]$} & {$[-3.60]$} & \\
\hline
\end{tabular}




\begin{tabular}{cccccc}
\hline \multicolumn{6}{l}{ Panel B: Coefficient of Error Correction terms } \\
\hline \multirow{6}{*}{$1 \mathrm{st}$} & $\mathrm{D}(\mathrm{InNSER})$ & $\mathrm{D}(\mathrm{InMS})$ & $\mathrm{D}(\mathrm{InCPI})$ & $\mathrm{D}(\mathrm{InEXR})$ & $\mathrm{D}(\mathrm{ATB})$ \\
& 0.003 & $-0.0030^{* * *}$ & $-0.0010^{* *}$ & $-0.0033^{* * *}$ & -0.0562 \\
& $(0.0032)$ & $(0.0005)$ & $(0.0005)$ & $(0.0009)$ & $(0.0653)$ \\
\multirow{3}{*}{ 2nd } & {$[0.94]$} & {$[-5.58]$} & {$[-2.13]$} & {$[-3.56]$} & {$[-0.86]$} \\
& 0.0082 & -0.0058 & $0.0079^{*}$ & $0.0276^{* * *}$ & $1.7776^{* * *}$ \\
& $(0.029)$ & $(0.0049)$ & $(0.0042)$ & $(0.0085)$ & $(0.5881)$ \\
\multirow{3}{*}{$3 \mathrm{rd}$} & {$[0.28]$} & {$[-1.18]$} & {$[1.90]$} & {$[3.26]$} & {$[3.02]$} \\
& 0.0142 & -0.001 & $0.0136^{*}$ & $0.0475^{* * *}$ & $3.0614^{* * *}$ \\
& $(0.05)$ & $(0.0055)$ & $(0.0072)$ & $(0.0146)$ & $(1.0129)$ \\
& {$[0.28]$} & {$[-1.18]$} & {$[1.90]$} & {$[3.26]$} & {$[3.02]$} \\
\hline
\end{tabular}

Note. Standard errors are in () and t-statistics []. 1st is the co-integration of InNSER with macroeconomic variables. 2nd is the co-integration of InCPI with other macroeconomic variables; $3 \mathrm{rd}$ is the co-integration of InMS with other macroeconomic variables. $* * *$ denotes significant at 0.01 level; ** denotes significant at 0.05 level; and * denotes significant at 0.1 level.

The VECM estimates indicate a long-run equilibrium relationship between the stock market index and the macroeconomic variables, and a second long-run equilibrium relationship between inflation and other macro variables.

Thus, we extract the following $\beta_{1}$ and $\beta_{2}$ matrixes for the two co-integrating vectors.

$y_{t}=\left(N S E R_{t}, M S_{t}, E X R_{t}, A T B_{t}\right)$

$\beta_{1}=(1.00,-1.683,13.954,0.239)$, and

$y_{t}=\left(C P I_{t}, M S_{t}, E X R_{t}, A T B_{t}\right)$

$\beta_{2}=(1.00,1.722,0.387,-0.059)$

Since these variables have been converted into their log transformations, they represent long-run elasticity measures, and thus can be re-expressed in the following two equations:

$$
\begin{aligned}
& I n N S E R=51.882-1.683 \operatorname{InMS}+13.954 \operatorname{InEXR}+0.239 A T B \\
& (-0.54) \quad(4.70) \quad(2.84) \\
& I n C P I=21.117+1.722 \operatorname{InMS}+0.384 \operatorname{InEXR}-0.059 A T B \\
& \begin{array}{lll}
(4.17) \quad(0.98) \quad(-5.29)
\end{array}
\end{aligned}
$$

The t-statistics are given in brackets. The coefficient for money supply in equation (a) is negative and statistically insignificant, while that of exchange rates and short-term interest rates are positive and statistically significant. The results from the first co-integration vector supports previous evidence from Olweny and Omondi (2011) which indicated that exchange rate and interest volatilities affect stock prices in Kenya. However, the results contradicts the evidence from Ouma and Muriu (2014), Ochieng and Oriwo (2012) and Aroni (2011), especially on the direction of the effects.

In equation (b) the evidence points to a long-run positive and statistically significant relationship between inflation and money supply, and a negative and statistically significant relationship between inflation and interest rates. Exchange rate has a positive though unimportant relationship with inflation.

The significant relationship between equilibrium inflation and money supply suggests that increase in money supply induces inflation in the Kenyan economy. Similarly, the significant negative equilibrium relationship between inflation and short-term interest rates suggests that the government interventions to mop up excess liquidity, characterized by high government borrowing rates (base rates), reduces inflation in the long-run. Given this evidence, the next empirical question then is how does the combined positive and negative effects of money supply, and interest rates respectively on inflation play in relation to stock prices in the long-run?

To examine this, the study imposes a restriction on the second co-integration vector to test the long-run equilibrium between money supply and other macro variables. The results of this test are presented as the third co-integration vector shown in the following matrix:

$y_{t}=\left(M S_{t}, C P I_{t}, E X R_{t}, A T B_{t}\right)$

$\beta_{3}=(1.00,0.581,0.224,-0.034)$

This could be expressed in the following equation since the values are log transformations. 


$$
\operatorname{InMS}=15.165+0.581 \operatorname{In} C P I+0.224 \operatorname{In} E X R-0.034 A T B
$$

The t-statics are in brackets. The results of the first co-integrating vector do not change with the restriction. As expected, there is a significant negative long-run equilibrium relationship between money supply and short-term interest rates. Inflation and exchange rates have a positive but insignificant relation with money supply. This evidence is consistent with the interventionary measures to mop up excess liquidity and contain inflationary shocks.

The coefficient of the error correction terms shows the short-run adjustment parameters $(\alpha)$, in the Johansen co-integration technique. From these results, money supply, inflation, and exchange rates have a negative and statistically significant short-term relationship with stock prices while short-term interest rates are negative but statistically insignificant. The stock market index parameter is positive but statistically insignificant. This would suggest that stock prices do respond to re-establish the long-run equilibrium relationship once deviation occurs.

The short-term dynamics for exchange rates and interest rates are consistent with earlier evidence reported by Ouma and Muriu (2014), Ochieng and Oriwo (2012) and Aroni (2011) who find a negative relationship between stock returns and the two variables. This implies that the evidence from these earlier studies capture only the short-term dynamics. Inflation and money supply short-term dynamics contradict evidence of a positive relation with stock prices as reported by the three studies, but remain consistent with economic theory of a negative long-run relation between inflation and aggregate output.

In summary, the co-integration results suggests that exchange rates and interest rates have positive long-run effects on stock prices while money supply has a negative long-run, but insignificant effect. Intuitively, the negative relationship between money supply and stock prices could be explained through the positive relationship with the intervening variable of inflation. The positive effect of interest rates on stock prices could be explained through the negative relationship with intervening variable of inflation. High short-term interest rates policy interventions help ease out inflation, and drive down long-run interest rates that consequently drive aggregate output in the long-run.

To examine the role of the intervening variables as a result of the second co-integrating vector, the study re-runs the Johansen technique at the 0.01 level. The results are presented in Table 7:

Table 7. Results of vector error correction model -0.01 levels

\begin{tabular}{|c|c|c|c|c|c|c|c|}
\hline \multicolumn{8}{|c|}{ Panel A: Johansen Normalized Co-integration Coefficients } \\
\hline & & InMS & InCPI & InEXR & ATM & Trend & Constant \\
\hline \multirow[t]{3}{*}{ InNSER } & 1.000 & $-11.177 * * *$ & -5.513 & $11.823 * * *$ & $0.565^{* * *}$ & $0.133^{*}$ & 59.276 \\
\hline & & $(3.117)$ & $(9.137)$ & $(2.984)$ & $(0.094)$ & $(0.07)$ & \\
\hline & & {$[-3.59]$} & {$[-0.60]$} & [3.96] & [5.98] & {$[1.90]$} & \\
\hline \multicolumn{8}{|c|}{ Panel B: Coefficient of Error Correction terms } \\
\hline & $\mathrm{D}(\mathrm{InNSER})$ & $\mathrm{D}(\mathrm{InMS})$ & $\mathrm{D}(\mathrm{InCPI})$ & $\mathrm{D}(\mathrm{InEXR})$ & $\mathrm{D}(\mathrm{ATB})$ & & \\
\hline & 0.002 & $-0.002 * * *$ & $-0.001 * * *$ & $-0.004 * * *$ & $-0.128 * *$ & & \\
\hline & $(0.003)$ & $(0.0005)$ & $(0.0004)$ & $(0.0008)$ & $(0.0568)$ & & \\
\hline & {$[0.66]$} & {$[-3.99]$} & {$[-2.78]$} & {$[-4.683]$} & {$[-2.25]$} & & \\
\hline
\end{tabular}

Note. Standard errors are in () and t-statistics []. *** denotes significant at 0.01 level; ** denotes significant at 0.05 level; and $*$ denotes significant at 0.1 level.

$y_{t}=\left(N S E R_{t}, C P I_{t}, M S_{t}, E X R_{t}, A T B_{t}\right)$

$* \beta_{1}=(1.00,-5.513,-11.177,11.823,0.565)$

This could again be re-written in the following equation:

$$
\operatorname{InNSR}=59.276-5.513 \operatorname{InCPI}-11.177 \operatorname{InMS}+11.823 \operatorname{InEXR}+0.565 \mathrm{ATB}
$$

$$
(-3.59) \quad(-0.60)
$$

The t-statistics are given in brackets. The results confirm a negative long-run equilibrium relationship between stock prices and inflation and money supply with money supply coefficient now statistically significant. The long-run equilibria relations between stock prices and exchange rates and short-term interest rates remain the same except for changes in the coefficient values. The short-run adjustment parameters remain the same in sign 
and statistical significance except for short-term interest rates that now become statistically significant.

\subsection{Causality Analysis}

Engel and Granger (1987) suggest that if variables are co-integrated, then there should exist a unidirectional or bidirectional relationship between the variables in the long-run. Unfortunately, the co-integration test only indicates that causality exists between the variables but fails to show the direction of the causal relationship (Naik \& Patel, 2012). Thus, the short-run and long-run causal relationship should be examined in a VECM framework. The system of short-run dynamics of the stock returns, corresponding to module (1) with long transformations can be written in the following VECM framework:

$$
\begin{gathered}
\Delta \operatorname{InNSER}_{t}=\mu_{1}+\gamma_{1} Z_{t-1}+\sum_{i=1}^{p} \theta_{1 i} \Delta \operatorname{InNSER}_{t-i}+\sum_{i=1}^{p} \delta_{1 i} \Delta \operatorname{InCPI} I_{t-i}+\sum_{i=1}^{p} \tau_{1 i} \Delta \operatorname{InMS}_{t-1} \\
+\sum_{i=1}^{p} \rho_{1 i} \Delta \operatorname{InEX} R_{t-i}+\sum_{i=1}^{p} \omega_{1 i} \Delta A T B_{t-i}+\varepsilon_{t}^{N S E R}
\end{gathered}
$$

Where: $Z_{t-1}$ is the error correction term obtained from the co-integrating vector; $\gamma, \theta, \delta, \tau, \rho$ and $\omega$ are the parameters to be estimated; $\mathrm{P}$ is the lag length; $\mu$ is a constant term and $\varepsilon^{N S E R}$ is assumed to be a stationary random process with mean zero and constant variance. The VECM for other variables can be expressed similarly.

Since the VECM captures both short-run dynamics and long-run equilibrium relations between the time series variables, it can thus distinguish between short-run and long-run Granger causality. A long-run Granger causality is provided by a significant coefficient of lagged error correction term (i.e. by testing $H_{0}: \gamma_{1}=1$ ), which can be observed through the t-statistics. The short-run Granger causality is tested by the joint significance of the coefficients of the differenced explanatory variables (Naik \& Patel, 2012). For example, inflation Granger cause stock market indices if either $\delta_{1 i}$ are jointly significant (by testing $H_{0}: \delta_{11}=\delta_{12} \ldots . .=\delta_{1 p}=0$ ). The short-run causality for other variables can be tested the same way.

The Granger causality analyses on the VECM based on 1 lag is done between the market indices, and the macroeconomic variables and the results summarized qualitatively in Table 8:

Table 8. Long-run and short-run granger causality based on VECM

\begin{tabular}{ccc}
\hline Variable & Long -run Causality & Short -run causality \\
\hline InCPI $\rightarrow$ InNSER & NO & NO \\
InNSER $\rightarrow$ InCPI & NO & NO \\
InMS $\rightarrow$ InNSER & YES* & NO \\
InNSER $\rightarrow$ InMS & NO & YES** \\
InEXR $\rightarrow$ InNSER & YES** & YES* \\
InNSER $\rightarrow$ InEXR & YES** & NO \\
ATB $\rightarrow$ InNSER & NO & YES* \\
InNSER $\rightarrow$ ATB & YES*
\end{tabular}

Note. $*$ denotes at lag $1 ; * *$ denotes no lag.

The results indicate that there exists a lagged unidirectional causality relationship between money supply and stock market index both in the short-run and long-run. The exchange rates indicate a contemporaneous bidirectional long-run relationship with the stock market index. However, in the short-run, while the causal relation remains bidirectional, the stock market index Granger causes exchange rates is lagged. Evidence also exists of a lagged causal relation between the stock market index and short-term interest rates (that is, stock market index Granger cause interest rates) both in the short-run and long-run. The results show no evidence of any causal relations between inflation and the stock market index.

\subsection{Robustness Test}

To test the robustness of the co-integration results, the study undertakes a multivariate regression analysis at three levels: a non-stationary process; a stationary process; and a stationary process with a lag inflation effect. The 3 regression equations are described below:

$$
\begin{gathered}
\operatorname{InNSER}_{t}=\beta_{0}+\beta_{1} \operatorname{InCPI}_{t}+\beta_{2} \operatorname{InMS}_{t}+\beta_{3} \operatorname{InEXR}_{t}+\beta_{4} A T B_{t}+\mu_{t} \\
\operatorname{DInNSER}_{t}=\beta_{0}+\beta_{1} \operatorname{DInCPI}_{t}+\beta_{2} D \operatorname{InM} S_{t}+\beta_{3} \operatorname{DInEX}_{t}+\beta_{4} D A T B_{t}+\mu_{t} \\
\operatorname{DInNSER}_{t}=\beta_{0}+\delta_{0} \operatorname{DInCPI}_{t}+\delta_{1} D \operatorname{InCPI} I_{t-1}+\delta_{2} D \operatorname{InMS} S_{t}+\delta_{3} \operatorname{DInEXR}_{t}+\delta_{4} D A T B_{t}+\mu_{t}
\end{gathered}
$$


Where: In are natural $\log$ terms; $\mathrm{D}$ are first difference terms; $\beta_{0}$ are constant terms; $\beta_{1}, \ldots ., \beta_{4}$ are the coefficients; $\delta_{0}, \ldots . ., \delta_{4}$ are coefficients with lag effect; and $\mu_{t}$ are error terms.

The results of the multivariate regressions are presented in table 9 below:

Table 9. Multivariate robustness test results

\begin{tabular}{|c|c|c|c|c|c|}
\hline \multicolumn{6}{|c|}{ Multivariate Regression Results } \\
\hline Variables & InCPI & InMS & InEXR & ATB & L1.InCPI \\
\hline \multicolumn{6}{|c|}{ Log results (Non stationary process) } \\
\hline Coefficients & 0.191 & $0.619 * * *$ & $-2.693 * * *$ & $-0.007 * *$ & \\
\hline Std. Errors & $(0.275)$ & $(0.167)$ & $(0.174)$ & $(0.003)$ & \\
\hline t-statistics & {$[0.70]$} & {$[3.71]$} & {$[-15.48]$} & {$[-2.19]$} & \\
\hline $\mathrm{R}^{2}$ & 0.751 & & & & \\
\hline Adj. $R^{2}$ & 0.747 & & & & \\
\hline \multicolumn{6}{|c|}{ First Difference results (Stationary process) } \\
\hline Coefficients & -0.303 & $0.628^{*}$ & $-0.598 * * *$ & -0.003 & \\
\hline Std. Errors & $(0.422)$ & $(0.354)$ & $(0.205)$ & $(0.003)$ & \\
\hline t-statistics & {$[-0.72]$} & {$[1.77]$} & {$[-2.92]$} & {$[-0.92]$} & \\
\hline $\mathrm{R}^{2}$ & 0.053 & & & & \\
\hline Adj. $R^{2}$ & 0.035 & & & & \\
\hline \multicolumn{6}{|c|}{ First Difference results with L1.InCPI } \\
\hline Coefficients & -0.304 & 0.608 & $-0.598 * * *$ & -0.003 & 0.000 \\
\hline Std. Errors & $(0.423)$ & $(0.369)$ & $(0.206)$ & $(0.003)$ & 0.000 \\
\hline t-statistics & {$[-0.72]$} & [1.65] & {$[-2.91]$} & {$[-0.93]$} & {$[0.20]$} \\
\hline $\mathrm{R}^{2}$ & 0.053 & & & & \\
\hline Adj. $R^{2}$ & 0.035 & & & & \\
\hline
\end{tabular}

These results indicate a positive but insignificant relationship between stock prices and inflation and a positive and statistically significant relationship between stock prices and money supply for the non-stationary process. The exchange rates and interest rates indicate negative and statistically significant relations with stock prices. The $\mathrm{R}^{2}$ and Adj. $\mathrm{R}^{2}$ are also particularly high at $75.1 \%$ and $74.7 \%$. The non stationary process results are consistent with earlier evidence documented by Ouma and Muriu (2014); OChieng and Oriwo (2012), and Aroni (2011).

Results on the stationary process show a reversal to a negative but statistically insignificant relationship between stock prices and inflation. Money supply remains positive but with a weaker relationship at the 0.1 confidence level. Exchange rates maintain a statistically significant relation with interest rates now reversing into statistical insignificance. $\mathrm{R}^{2}$ and Adj. $\mathrm{R}^{2}$ become surprisingly small at $5.3 \%$ and $3.5 \%$ respectively. First difference regression results are consistent with the short-term dynamics reported by the Johansen co-integration process, and capture the negative long-run equilibrium relationship between stock prices and inflation with the weakening positive effects of money supply.

Finally, first difference estimates (lag inflation) results indicate the positive money supply effect becomes insignificant. This confirms that ultimately, the inflation effects outweighs the positive money supply influence and thus explain negative long-run equilibrium relationship reported under the co-integration results. The multivariate results point to the possibility of spurious problems on evidence adduced in earlier studies for the Kenyan market.

\section{Conclusion}

This study sought to examine the effects of volatility of selected macroeconomic variables on the stock market prices in Kenya. Evidence suggests a negative equilibrium relationship for money supply and a positive relation for exchange rates and interest rates with stock prices in the long-run. Inflation shows a negative but insignificant relation with stock prices in the long-run. This evidence is contrary to earlier documented evidence on the Kenyan market that suggests a positive correlation for money supply and inflation, and negative relations for exchange rates and interest rates.

This evidence supports the monetary policy adopted by the Government of Kenya since the early 2000's to maintain inflation in the 1 digit level and contain high lending interest rates by commercial banks. In the absence 
of data for industrial production (or a suitable proxy), the earlier documented positive correlation between stock returns and money supply would appear to fit into the Lucas (1972) model economy theory.

The limitations of this study cannot be overlooked in that only a limited number of macroeconomic variables are studied. It would particularly be interesting to examine how the evidence could evolve with a good variable that can measure (or proxy) firm aggregate output. Currently, reliable data on the commonly used industrial production index in Kenya is unavailable and/or too short to model for long run relations.

\section{Acknowledgments}

I take this opportunity to sincerely thank Prof. Zhang Xueyong (my academic supervisor) and Prof. Xian Gu (my Advanced Econometric course instructor where the very initial draft was presented as a term paper) for their guidance and support in the course of preparing this paper.

\section{References}

Akbar, M., Ali, S. K., \& Khan, F. (2012). The Relationship of Stock Prices and Macroeconomics Variables Revisited: Evidence from Karachi Stock Exchange. Africa Journal of Business Management, 6(4), 1351-1322.

Aroni, J. M. (2011). Factors Influencing Stock Prices for Firms Listed in the Nairobi Stock Exchange. International Journal of Business and Social Science, 2(20).

Aurangzeb. (2012). Factors Affecting Performance of Stock Markets: Evidence from South Asian Countries. International Journal of Academic Research in Business and Social Sciences, 2(9).

Benakovic, D., \& Posedel, P. (2010). Do Macroeconomic Factors Matter for Stock Returns? Evidence from Estimating a Multifactor Model on the Croatian Market. Working Paper Series, paper No. 10-12. https://doi.org/10.2478/v10305-012-0023-z

Borys, M. M. (2007). Testing Multi-Factor Asset Pricing Models in the Visegrad Countries. CERGI-EI, Working Paper Series 323 (ISSN 1211 -3298), March 2007, Electronic version.

Brooks, C. (2002). Introductory Econometrics for Finance (2nd ed.). Cambridge University Press.

Carhart, M. M. (1997). On Persistence in Mutual Fund Performance. Journal of Finance, 52(1), 57-82. https://doi.org/10.1111/j.1540-6261.1997.tb03808.x

Central Bank of Kenya. (2016). Statistics. Nairobi. Retrieved April 2016 from http://www.centralbank.go.ke/index.php/rate-and-statistics/exchange

Chen, N., Roll, R., \& Ross, S.A. (1986). Economic Forces and the Stock Market. Journal of Business, 59, 383-403. https://doi.org/10.1086/296344

Coleman, A. K., \& Tetty, F.A. (2008). Impact of Macroeconomic Variables on Ghana Stock Exchange. Journal of Risk and Finance, 4, 365-378. http://dx.doi.org/10.1108/15265940810895025

De Jong, F., \& De -Roon, F. A. (2001). Time Varying Market Integration and Expected Returns in Emerging Markets. Centre Discussion Paper No. 78. http://dx.doi.org/10.1016/j.jfineco.2004.10.010

Enders, W. (2004). Applied Econometric Time Series (2nd ed.) Wiley Series in Probability and Statistics.

Engel, R. F., \& Granger, W. J. (1987). Co-integration and Error Correction: Representation, Estimation and Testing. Econometrica, 55(2), 251-276. https://doi.org/10.2307/1913236

Erb, C., Harvey, C., \& Viskanta, T. (1995). Country Risk and Global Equity Selection. Journal of Portfolio Management, Winter, 74-83. https://doi.org/10.3905/jpm.1995.409504

Erb, C., Harvey, C., \& Viskanta, T. (1996). Expected Returns and Volatility in 135 countries. Portfolio Management, Spring, 46-58. https://doi.org/10.3905/jpm.1996.409554

Ericsson, J., \& Karlsson, S. (2004). Choosing Factors in a Multifactor Asset Pricing Model: A Bayesian Approach. Stockholm School of Economics, SSE/EFI Working Paper Series in Economics and Finance No. 524, February 2004.

Fama, E. F., \& French, K. R. (1993). Common Risk Factors in the Returns of Stocks and Bonds. Journal of Financial Economics, 33, 3-56. https://doi.org/10.1016/0304-405X(93)90023-5

Flannery, M. J., \& Protopapadakis, A. A. (2002). Macroeconomic Factors Do Influence Aggregate Stock Returns. The Review of Financial Studies, 15(3), 751-782. https://doi.org/10.1093/rfs/15.3.751

Harvey, C. R. (1995). Predictable Risk and Returns in Emerging Markets. The Review of Financial Studies, 8(3), 
773-816. https://doi.org/10.1093/rfs/8.3.773

Johansen, S. (1991). Estimation and Hypothesis Testing of Co-integration Vector in Gaussian Vector Autoregression Models. Econometrica, 59, 1551-1581. https://doi.org/10.2307/2938278

Johansen, S., \& Juselius, K. (1990). Maximum Likelihood Estimation and Inference on Co-integration with application to the Demand for Money. Oxford Bulletin of Economics and Statistics, 52(2), 169-210. https://doi.org/10.1111/j.1468-0084.1990.mp52002003.x

Kumar, R. (2013). The Effect of Macroeconomic Factors on the Indian Stock Market Performance: A Factor Analysis Approach. Journal of Economics and Finance, 1(3), 14-21.

Lakonishok, J., \& Shapiro, A. C. (1986). Systematic Risk, Total Risk, and Size as Determinants of Stock market Returns. Journal of Banking and Finance, 10, 115-132. https://doi.org/10.1016/0378-4266(86)90023-3

Naik, K. P., \& Padhi, P. (2012). The Impact of Macroeconomic Fundamentals on Stock Prices Revisited: Evidence from Indian data. Eurasian Journal of Business and Economics, 5(10), 25-44.

Ochieng, D. E., \& Oriwo, E. A. (2012). The Relationship between Macro-economic variables and Stock Market Performance in Kenya. DBA Africa Management Review, 3(1), 38-49.

Olweny, T., \& Omondi, K. (2011). The Effect of Macro-economic Factors on Stock Return Volatility in the Nairobi Stock Exchange, Kenya (Article). Journal of Economic and Finance Review, 1(10), 34.

Ouma, W. N., \& Muriu, P. (2014). The Impact of Macroeconomic Variables on Stock Market Returns in Kenya. International Journal of Business and Commerce, 3(11).

Pal, K., \& Mittal, R. (2011). Impact of Macroeconomic Indicators on Indian Capital Markets. Journal of Risk Finance, 12(2), 84-97. https://doi.org/10.1108/15265941111112811

Patel, S. (2012). The Effect of Macroeconomic Determinants on the Performance of the Indian Stock Market. NMIMS Management Review, XXII.

Reinganum, M. (1981). Misspecification of Capital Asset Pricing: Empirical Anomalies. Journal of Financial Economics, 9, 19-46. https://doi.org/10.1016/0304-405X(81)90019-2

Talla, J. T. (2013). Impact of Macroeconomic Variable on the Stock Market Prices of the Stockholm Stock Exchange (OMXS30). A Masters thesis, Jonkoping International Business University, May 2013.

Tangjitprom, N. (2012). Macroeconomic Factors of Emerging Stock Markets: The Evidence from Thailand. International Journal of Financial Research, 3(2). http://dx.doi.org/10.5430/ijfr.v3n2p105

Wooldridge, J. M. (2013). Introductory Econometrics: A Modern Approach (5th ed., pp. 344-373). South-Western GENGAGE Learning: Michigan State University.

\section{Note}

Note 1. M1 includes MO (Currency in circulation- Cash in bank till- Commerative coins) + Other deposits at CBK + Demand deposits in Banks.

\section{Copyrights}

Copyright for this article is retained by the author(s), with first publication rights granted to the journal.

This is an open-access article distributed under the terms and conditions of the Creative Commons Attribution license (http://creativecommons.org/licenses/by/4.0/). 